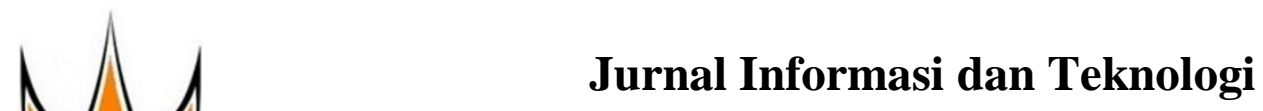

http://www.jidt.org

2021 Vol. $3 \quad$ No. $2 \quad$ Hal: 78-83 ISSN: 2714-9730 (electronic)

\title{
Simple Additive Weighting dalam Penyaluran Dana Bantuan Sekolah Dasar
}

\author{
Afifah Trista Ayunda ${ }^{1 凶}$, Sarjon Defit ${ }^{2}$, Gunadi Widi Nurcahyo ${ }^{3}$ \\ ${ }^{1,2,3}$ Universitas Putra Indonesia YPTK Padang \\ afifahayunda22@gmail.com
}

\begin{abstract}
School grants are the distribution of education funds for elementary schools sourced from the Boss Performance (Bos Kinerja). Boss Performance or school operational assistance is allocated for schools that are considered to have good performance. The issues that often arise is the distribution of school aid funds that are not on target, this is due to the absence of a method for distributing these funds, which has affect on the performance of the school education unit. Decision support systems with Simple Additive Weighting (hereinafter reffered to as SAW) method are used to encourage the quality of education services for elementary schools which are considered to have good performance in educational units. Moreover, its facilitate in making and supporting decisions in the distribution of elementary school assistance funds. In the result of this study found the final result 100 percent accuracy therefore adoption of the Simple Additive Weighting method helps in making decisions that are right on target in distributing primary school grants.
\end{abstract}

Keywords: Performance Boss, Elementary School, Aid Fund, DSS, Simple Additive Weighting.

\begin{abstract}
Abstrak
Dana bantuan sekolah adalah penyaluran dana pendidikan bagi sekolah dasar yang bersumber dari Bos Kinerja. Bos Kinerja atau bantuan operasional sekolah di peruntukan bagi sekolah yang dinilai memilki kinerja yang baik. Kendala yang sering timbul yaitu penyaluran dana bantuan sekolah yang tidak tepat sasaran, hal tersebut diakibatkan tidak terdapatnya metode dalam penyaluran dana tersebut, sehingga berdampak kepada kinerja satuan pendidikan sekolah. Sistem pendukung keputusan menggunakan metode Simple Additive Weighting (SAW) digunakan untuk mendorong mutu layanan pendidikan bagi sekolah dasar yang dinilai memiliki kinerja baik dalam satuan pendidikan. Sistem tersebut berfungsi mempermudah dalam pengambilan maupun pendukung keputusan dalam penyaluran dana bantuan sekolah dasar. Pada penelitian ini diperoleh hasil akhir akurasi $100 \%$ dengan demikian pengadopsian metode Simple Additive Weighting membantu dalam pengambilan keputusan yang tepat sasaran dalam penyaluran dana bantuan sekolah dasar.
\end{abstract}

Kata kunci: Bos Kinerja, Sekolah Dasar, Dana Bantuan, SPK, Simple Additive Weighting.

(c) 2021 JIdT

\section{Pendahuluan}

Dana bantuan sekolah adalah pemberian dana pendidikan bagi sekolah dasar yang bersumber dari Bos Kinerja atau bantuan operasional sekolah yang di peruntukan bagi sekolah yang memiliki kinerja yang baik. Sumber dana Bos Kinerja berasal dari anggaran pendapatan belanja negara. Dana tersebut disalurkan kepada sekolah-sekolah lingkungan pendidikan.

Kendala yang sering timbul dalam penyaluran dana bantuan ialah penyaluran dana bantuan sekolah yang tidak tepat sasaran. Hal ini diakibatkan tidak terdapatnya metode dalam penyaluran dana tersebut, sehingga berdampak kepada kinerja satuan pendidikan sekolah.

Penelitian-penelitian sebelumnya pernah mengadopsi metode Simple Additive Weighting (SAW) dalam berbagai bidang permasalahan. Penerapan SAW berhasil digunakan untuk menentukan siswa terbaik secara objektif setiap kelas untuk Bina Iman Anak Pandu Schooll [1]. Sama halnya SAW digunakan untuk mendukung keputusan penentuan gaji karyawan dalam membantu kinerja manager [2].

Penelitian lain terkait SAW digunakan untuk seleksi dosen berprestasi berdasarkan kriteria tertentu menggunakan 20 sampel dinyatakan efektif dalam pengambilan keputusan [3]. Sama halnya dengan pemilihan kepala sekolah berprestasi di Kabupaten Kuantan Singigi, metode SAW di aplikasikan kedalam sistem untuk mempermudah proses pemilihan menjadi lebih efektif, efisien dan transparan [4].

SAW dalam penelitian lain ditemukan efektif untuk menentukan kualitas telur puyuh berkualitas berdasarkan kriteria dengan tujuan membantu peternak menghasilkan telur yang bernilaian gizi baik bagi masyarakat [5]. Kemudian penelitian terkait SAW juga lakukan untuk menentukan kombinasi jenis kakao atau kombinasi kakao yang optimal dalam bahan minuman coklat panas [6].

Penelitian berikutnya digunakan untuk pemilihan jaringan pada jaringan nirkabel heterogen dengan tujuan mengoptimalkan kepuasan pengguna [7]. Penentuan prioritas penyediaan bahan baku sepatu didapatkan hasil 
sama antara perhitungan manual dengan perhitungan $\mathrm{y}_{\mathrm{ef}} \quad=$ Baris dan kolom dari matriks atau nilai atribut sistem [8]. Dan membantu pengambilan keputusan yang yang dimiliki oleh setiap kriteria.

optimal dalam merekomendasikan supplier terbaik [9]. Lalu penelitian lain dalam penilaian kecerdasan anak pada taman kanak-kanak [10].

Berdasarkan pemaparan yang telah disebutkan di atas, Keuntungan $($ Benefit $)=$ jika nilai terbesar merupakan yang terbaik.

untuk mendorong mutu layanan pendidikan bagi sekolah dasar yang dinilai memiliki kinerja baik dalam satuan pendidikan dibutuhkan suatu sistem dalam menentukan penyaluran dana bantuan yang tepat sasaran dengan menggunakan Simple Additive Weighting. Sistem tersebut berfungsi mempermudah dalam pengambilan maupun pendukung keputusan dalam penyaluran dana bantuan sekolah dasar.

\section{Metodologi Penelitian}

Decision Support System (DSS) yang dikenal dengan Sistem Pendukung Keputusan adalah sistem untuk mengotomatisasi pengambilan keputusan, namun memberikan perangkat interkatif yang memungkinkan dalam mendukung pembuatan keputusan dalam bermacam analisis menggunakan model- model yang tesedia [11]. SPK merupakan sistem berbasis computer interaktif dimana data dan model analisis merupakan komponen utama yang digunakan oleh pengambil keputusan untuk memecahkan masalah yang tidak terstruktur [12]. DSS bertujuan sebagai alat bagi pembuat keputusan untuk mengembangkannya kemampuan, tetapi tidak untuk menggantikan penilaian pemimpin atau manajer [13]. SPK dirancang untuk mendukung tahapan pengambilan keputusan diawali dari mengidentifikasi masalah, memilih data yang relevan, dan menentukan pendekatan berfungsi dalam proses pengambilan keputusan, terakhir untuk mengevaluasi pemilihan alternatif [14].

Simple Addtive Weighting disingkat dengan SAW merupakan metode pembobotan sederhana atau penjumlahan terbobot dengan konsep dasar mencari jumlah tertimbang penilaian kinerja setiap akternatif dimasing-masing atribut [15]. Konsep mendasar dari metode SAW yaitu pencarian rating kinerja (skala prioritas) setiap alternatif [16]. Algoritma penyelesaikan metode ini di jabarkan sebagai berikut:

a. Mendefenisikan terlebih dahulu kriteria yang dijadikan sebagai aturan penyelesaikan masalah.

b. Menormalisasikan setiap nilai alternatif pada setiap atribut dengan menghitung nilai rating kinerja.

$$
n_{e f}=\left\{\begin{array}{c}
\llbracket \frac{x_{e f}}{M a x_{e} x_{e f}}, f \text { adalah atribut keuntungan } \\
\frac{M n_{i} x_{e f}}{x_{e f}}, f \text { adalah atribut biaya }
\end{array} \|\right.
$$

Biaya $($ Cost $)=$ jika nilai terkecil merupakan yang terbaik .

Dimana $\mathrm{n}_{\mathrm{ef}}$ adalah peringkat kinerja ternormalisasi dari alternatif Se pada atribut Qf; e $=1,2, \ldots \mathrm{m}$ dan $\mathrm{f}=1,2, . . \mathrm{n}$.

c. Menghitung nilai bobor preferensi setiap alternatif.

$$
P_{e}=\sum_{f=1}^{x} Q_{f} n_{e f}
$$

Dimana:

$P_{e}=$ Nilai bobot preferensi dari setiap alternatif.

$T_{f}=$ Nilai bobot kinerja atau nilai tertimbang dari setiap kriteria.

$n_{e f}=$ Nilai rating kinerja ternormalisasi.

Nilai Pe yang lebih besar menunjukkan bahwa alternatif Se lebih disukai.

d. Melakukan perangkingan dari rating tertinggi ke terendah.

Pada metodologi penelitian yang dilakukan dalam rangka penyelesaian masalah yang akan diteliti, dimulai dari memperoleh data- data yang diperlukan, memproses data menjadi informasi yang sesuai dengan penelitian dengan tujuan sebagai pedoman dalam melakukan penelitian agar hasil tidak menyimpang dari tujuan sebenarnya yang dijabarkan melalui kerangka kerja penelitian. Berikut kerangka kerja penelitian terlihat pada Gambar 1.

Dimana :

$n_{e f} \quad=$ Nilai peringkat kinerja dinormalisasikan.

$\operatorname{Max}_{e f}=$ Nilai maksimum dari setiap kriteria.

$\operatorname{Min}_{\text {ef }}=$ Nilai minimum dari setiap kriteria. 
Afifah Trista Ayunda, Sarjon defit, Gunadi Widi Nurcahyo.

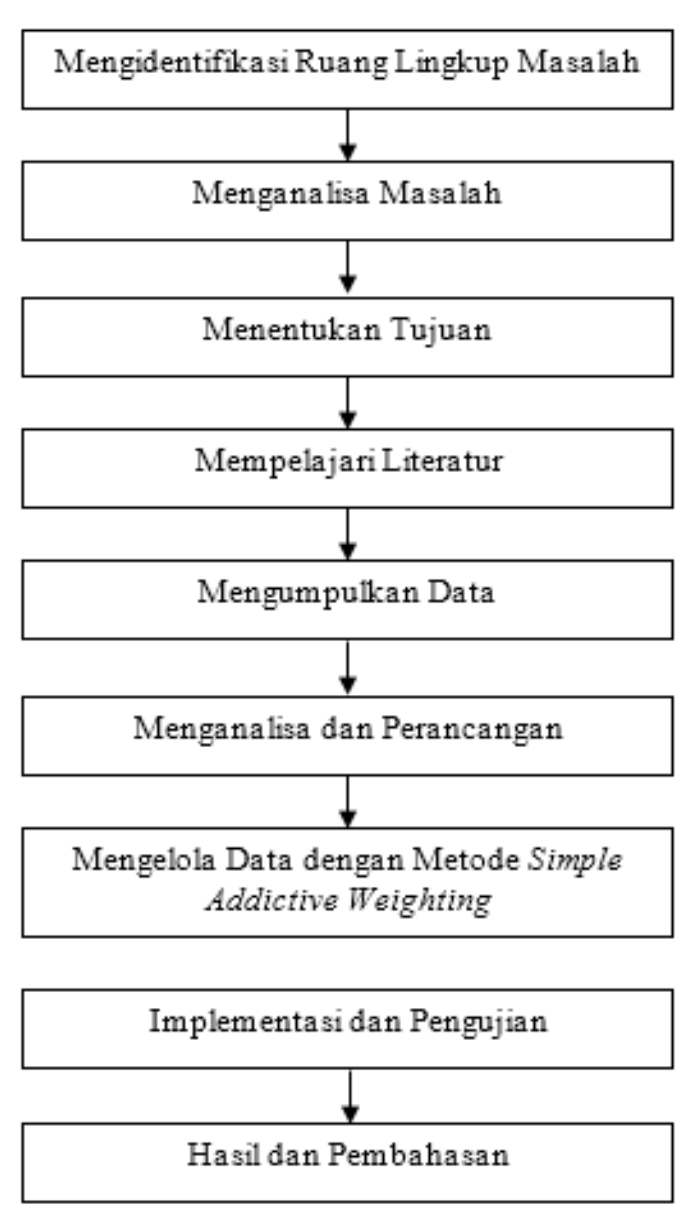

Gambar 1. Kerangka Kerja Penelitian

\section{Hasil dan Pembahasan}

\subsection{Hirarki Penyaluran Dana Bantuan}

Hirarki merupakan suatu struktur pemodelan yang memberikan kesempatan untuk membangun gagasangagasan dan mendefenisikan persoalan dengan cara membuat asumsi masing- masing dan memperoleh pemecahan yang diinginkan. Dengan menyusun menjadi level-level sepeti yang terlihat pada Gambar 2.

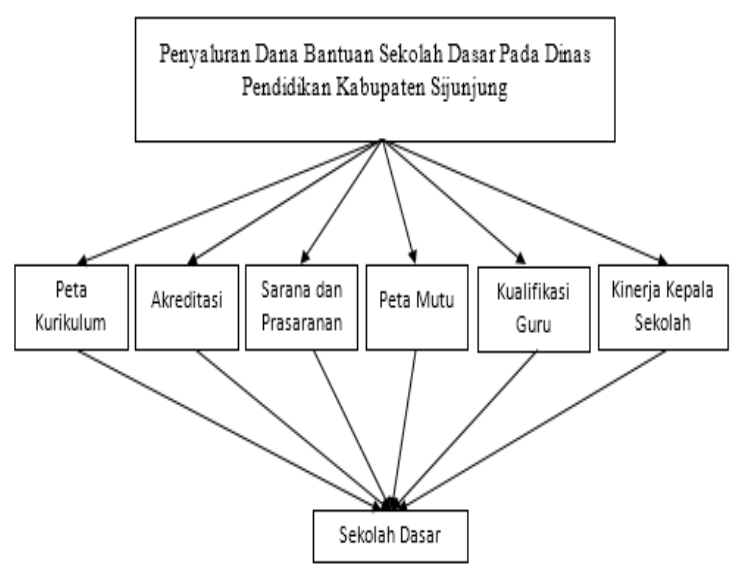

Gambar 2. Hirarki Penyaluran Dana Bantuan Sekolah Dasar Pada Dinas Pendidikan Kabupaten Sijunjung

\subsection{Analisis Hasil}

Dalam proses Sistem Pendukung Keputusan untuk menentukan sekolah dasar yang tepat menerima dan bantuan sekolah, dibutuhkan untuk menentukan kriteria pada tahap pertama dalam metode Simple Addictive Weighting.

Kriteria dan pembobotan telah di tetapkan berjumlah 6 (enam) Penginisialan kriteria pada Tabel 1 mengunakan huruf Q yaitu kriteria yaitu Q1 sampai Q6. Perolehan nilai kriteria didapatkan dari tingkat keputusan paling tinggi pada objek penelitian. Kriteria yang digunakan tersebut terdapat pad Tabel 1.

\begin{tabular}{ccl}
\multicolumn{2}{c}{ Tabel 1. Kriteria } \\
\hline No & $\begin{array}{l}\text { Kode } \\
\text { Kriteria }\end{array}$ & Kriteria \\
\hline 1 & Q1 & Peta Kurikulum \\
2 & Q2 & Akreditasi \\
3 & Q3 & Sarana dan Prasarana \\
4 & Q4 & Peta Mutu \\
5 & Q5 & Kualifikasi Guru \\
6 & Q6 & Kinerja Kepala Sekolah \\
\hline
\end{tabular}

Penetapan bobot preferensi atau tingkat kepentingan (T) setiap kriteria. Hasil dari penentuan bobot preferensi dapat dilihat pada Tabel 2.

\begin{tabular}{cclc}
\multicolumn{3}{c}{ Tabel 2. Bobot Preferensi } \\
\hline No & $\begin{array}{l}\text { Kode } \\
\text { Kriteria }\end{array}$ & Kriteria & Bobot \\
\hline 1 & Q1 & Peta Kurikulum & 0.30 \\
2 & Q2 & Akreditasi & 0,05 \\
3 & Q3 & Sarana dan Prasarana & 0,10 \\
4 & Q4 & Peta Mutu & 0,20 \\
5 & Q5 & Kualifikasi Guru & 0,05 \\
6 & Q6 & Kinerja Kepala Sekolah & 0,30 \\
\hline
\end{tabular}

Pembobotan pada Tabel 2 didapat nilai bobot peneliti tentukan berdasarkan tingkat kepentingan masing-masing kriteria dengan jumlah 1 dengan persentasi $100 \%$. Dan penilaian rating kecocokan sub kriteria dengan skala keseluruhan penilaian alternatif yang terdapat pada Tabel 3.

Tabel 3. Rating Kecocokan

\begin{tabular}{lc}
\hline \multicolumn{1}{c}{ Skala Penilaian } & Nilai \\
\hline Tinggi (Sangat Baik) & 5 \\
Sedang (Baik) & 3 \\
Rendah (Cukup Baik) & 1 \\
\hline
\end{tabular}

Data yang digunakan berjumlah 30 data sampel yang di olah sesuai dengan data sebenarnya berdasarkan kriteria yang telah ditetapkan sebelumnya. Data tersebut terdapat pada Tabel 4. 
Afifah Trista Ayunda, Sarjon defit, Gunadi Widi Nurcahyo.

\begin{tabular}{cl}
\hline & Tabel 4. Alternatif \\
\hline Kode & Nama Sekolah \\
\hline S1ternatif & SDN 37 Durian Gadang \\
S02 & SDN 7 Kabun \\
S03 & SDN 6 Padang Sibusuk \\
S04 & SDN 13 Pulasan \\
S05 & SDN 8 Silongo \\
S06 & SDN 4 Batu Manjulur \\
S07 & SDN 38 Solok Ambah \\
S08 & SDN 34 Durian Gadang \\
S09 & SDN 28 Sisawah \\
S10 & SDN 27 Tamparungo \\
S11 & SDN 3 Langki \\
S12 & SDN 8 Koto Baru \\
S13 & SDN 7 Durian Gadang \\
S14 & SDN 15 Unggan \\
S15 & SDN 9 Manganti \\
S16 & SDN 13 Tanjung Bonai Aur \\
S17 & SDN 12 Solok Ambah \\
S18 & SDN 25 Sisawah \\
S19 & SDN 2 Unggan \\
S20 & SDN 23 Pulasan \\
S21 & SDN 23 Tanjung Bonai Aur \\
S22 & SDN 22 Pulasan \\
S23 & SDN 14 Sisawah \\
S24 & SDN 16 Silantai \\
S25 & SDN 17 Tamparungo \\
S26 & SDN 24 Tanjung Lolo \\
S27 & SDN 17 Kampung Dalam \\
S28 & SDN 3 Tamparung \\
S29 & SDN 8 Sungai Bantuang \\
S30 & SDN 11 Palaluar \\
\hline & \\
\hline
\end{tabular}

Data berdasarkan skala penilaian untuk masing- masing alternatif (Se) berdasarkan sub kriteria (Qn) .Nilai tersebut terlebih dahulu dikonversi menjadi angka yang terdapat pada Tabel 5 .

Data- data masing-masing alternatif Sn yang telah dinilai dengan bobot yang telah ditetapkan, lalu di buat matriks keputusan (X). Matriks keputusan (X) dibentuk dari tabel rating kecocokan setiap alternatif (Se). Kemudian di lakukan normalisasi matrik keputusan $(\mathrm{X})$ dengan cara menghitung nilai rating kinerja ternormalisasi $\left(\mathrm{n}_{\mathrm{ef}}\right)$ dari alternatif (Se) pada kriteria (Qf).
Tabel 5. Data Penilaian Terbobot

\begin{tabular}{|c|c|c|c|c|c|c|}
\hline $\begin{array}{c}\text { Kode } \\
\text { Alternatif }\end{array}$ & Q1 & $\mathrm{Q} 2$ & Q3 & Q4 & Q5 & Q6 \\
\hline S01 & 3 & 3 & 5 & 1 & 1 & 3 \\
\hline S02 & 3 & 3 & 5 & 1 & 3 & 5 \\
\hline S03 & 5 & 3 & 3 & 5 & 3 & 5 \\
\hline S04 & 3 & 3 & 5 & 5 & 3 & 3 \\
\hline S05 & 1 & 3 & 3 & 5 & 3 & 5 \\
\hline S06 & 3 & 3 & 1 & 5 & 1 & 3 \\
\hline S07 & 1 & 1 & 1 & 1 & 5 & 1 \\
\hline S08 & 1 & 3 & 5 & 1 & 1 & 1 \\
\hline S09 & 5 & 3 & 5 & 5 & 1 & 1 \\
\hline $\mathrm{S} 10$ & 3 & 1 & 5 & 5 & 1 & 3 \\
\hline S11 & 1 & 1 & 5 & 1 & 1 & 1 \\
\hline $\mathrm{S} 12$ & 1 & 5 & 5 & 5 & 1 & 1 \\
\hline $\mathrm{S} 13$ & 1 & 3 & 1 & 5 & 1 & 3 \\
\hline S14 & 5 & 3 & 5 & 5 & 5 & 5 \\
\hline S15 & 3 & 5 & 5 & 1 & 1 & 3 \\
\hline S16 & 1 & 3 & 5 & 5 & 5 & 5 \\
\hline $\mathrm{S} 17$ & 3 & 3 & 1 & 1 & 1 & 3 \\
\hline S18 & 5 & 1 & 5 & 5 & 3 & 5 \\
\hline S19 & 3 & 3 & 5 & 5 & 1 & 5 \\
\hline $\mathrm{S} 20$ & 3 & 1 & 3 & 1 & 1 & 3 \\
\hline $\mathrm{S} 21$ & 3 & 1 & 3 & 5 & 1 & 5 \\
\hline $\mathrm{S} 22$ & 1 & 3 & 5 & 5 & 1 & 1 \\
\hline $\mathrm{S} 23$ & 3 & 3 & 5 & 5 & 5 & 5 \\
\hline $\mathrm{S} 24$ & 1 & 3 & 3 & 5 & 3 & 3 \\
\hline $\mathrm{S} 25$ & 1 & 1 & 3 & 1 & 1 & 1 \\
\hline S26 & 1 & 3 & 5 & 1 & 3 & 5 \\
\hline S27 & 3 & 3 & 3 & 1 & 3 & 5 \\
\hline S28 & 3 & 3 & 3 & 5 & 1 & 5 \\
\hline $\mathrm{S} 29$ & 3 & 3 & 3 & 5 & 1 & 5 \\
\hline $\mathrm{S} 30$ & 3 & 3 & 5 & 5 & 1 & 1 \\
\hline
\end{tabular}

Hasil dari rating kinerja ternormalisasi $\left(\mathrm{n}_{\mathrm{ef}}\right)$ membentuk matriks ternormaliasi (n).

$\mathrm{n}_{\mathrm{ef}}=\left[\begin{array}{cccccc}0,60 & 0,60 & 1,00 & 0,20 & 0,20 & 0,60 \\ 0,60 & 0,60 & 1,00 & 0,20 & 0,60 & 1,00 \\ 1,00 & 0,60 & 0,60 & 1,00 & 0,60 & 1,00 \\ 0,60 & 0,60 & 1,00 & 1,00 & 0,60 & 0,60 \\ 0,20 & 0,60 & 0,60 & 1,00 & 0,60 & 1,00 \\ 0,60 & 0,60 & 0,20 & 1,00 & 0,20 & 0,60 \\ 0,20 & 0,20 & 0,20 & 0,20 & 1,00 & 0,20 \\ 0,20 & 0.60 & 1,00 & 0,20 & 0,20 & 0,20 \\ 1,00 & 0,60 & 1,00 & 1,00 & 0,20 & 0,20 \\ 0,60 & 0,20 & 1,00 & 1,00 & 0,20 & 0,60 \\ 0,20 & 0,20 & 1,00 & 0,20 & 0,20 & 0,20 \\ 0,20 & 1,00 & 1,00 & 1,00 & 0,20 & 0,20 \\ 0,20 & 0.60 & 0,20 & 1,00 & 0,20 & 0,60 \\ 1,00 & 0,60 & 1,00 & 1,00 & 1,00 & 1,00 \\ 0,60 & 1,00 & 1,00 & 0,20 & 0,20 & 0,60 \\ 0,20 & 0,60 & 1,00 & 1,00 & 1,00 & 1,00 \\ 0,60 & 0,60 & 0,20 & 0,20 & 0,20 & 0,60 \\ 1,00 & 0,20 & 1,00 & 1,00 & 0,60 & 1,00 \\ 0,60 & 0,60 & 1,00 & 1,00 & 0,20 & 1,00 \\ 0,60 & 0,20 & 0,60 & 0,20 & 0,20 & 0,60 \\ 0,60 & 0,20 & 0,60 & 1,00 & 0,20 & 1,00 \\ 0,20 & 0,60 & 1,00 & 1,00 & 0,20 & 0,20 \\ 0,60 & 0,60 & 1,00 & 1,00 & 1,00 & 1,00 \\ 0,20 & 0,60 & 0,60 & 1,00 & 0,60 & 0,60 \\ 0,20 & 0,20 & 0.60 & 0,20 & 0,20 & 0,20 \\ 0,20 & 0,60 & 1,00 & 0,20 & 0,60 & 1,00 \\ 0,60 & 0,60 & 0,60 & 0,20 & 0,60 & 1,00 \\ 0,60 & 0,60 & 0,60 & 1,00 & 0,20 & 1,00 \\ 0,60 & 0,60 & 0,60 & 1,00 & 0,20 & 1,00 \\ 0,60 & 0,60 & 1,00 & 1,00 & 0,20 & 0,20\end{array}\right]$

Hasil nilai rating kinerja ternormalisasi $\left(\mathrm{n}_{\mathrm{ef}}\right.$ dari alternatif (Se) pada kriteria (Qf) di dapat, kemudian dilakukan proses perhitungan untuk mendapatkan hasil akhir preferensi (Pe) yang diperoleh dari penjumlahan dan perkalian elemen baris matriks ternormalisasi (n) dengan 
preferensi (T) yang bersesuaian dengan elemen kolom matriks. Berikut proses perhitungan untuk hasil akhir preferensi $(\mathrm{Pe})$.

$\mathrm{P} 1=(0,60 * 0,3)+(0,60 * 0,05)+(1,00 * 0,1)+(0,20 * 0,2)+(0,20 * 0,05)+(0,60 * 0,3)=0,54$

$\mathrm{P} 2=(0,60 * 0,3)+(0,60 * 0,05)+(1,00 * 0,1)+(0,20 * 0,2)+(0,60 * 0,05)+(1,00 * 0,3)=0,68$

$\mathrm{P} 3=(1,00 * 0,3)+(0,60 * 0,05)+(0,60 * 0,1)+(1,00 * 0,2)+(0,60 * 0,05)+(1,00 * 0,3)=0,92$

$\mathrm{P} 4=(0,60 * 0,3)+(0,60 * 0,05)+(1,00 * 0,1)+(1,00 * 0,2)+(0,60 * 0,05)+(0,60 * 0,3)=0,72$

$\mathrm{P} 5=(0,20 * 0,3)+(0,60 * 0,05)+(0,60 * 0,1)+(1,00 * 0,2)+(0,60 * 0,05)+(1,00 * 0,3)=0,68$

$\mathrm{P} 6=(0,60 * 0,3)+(0,60 * 0,05)+(0,20 * 0,1)+(1,00 * 0,2)+(0,20 * 0,05)+(0,60 * 0,3)=0,62$

$\mathrm{P} 7=(0,20 * 0,3)+(0,20 * 0,05)+(0,20 * 0,1)+(0,20 * 0,2)+(1,00 * 0,05)+(0,20 * 0,3)=0,24$

$\mathrm{P} 8=(0,20 * 0,3)+(0,60 * 0,05)+(1,00 * 0,1)+(0,20 * 0,2)+(0,20 * 0,05)+(0,20 * 0,3)=0,30$

$\mathrm{P} 9=(1,00 * 0,3)+(0,60 * 0,05)+(1,00 * 0,1)+(1,00 * 0,2)+(0,20 * 0,05)+(0,20 * 0,3)=0,70$

$\mathrm{P} 10=(0,60 * 0,3)+(0,20 * 0,05)+(1,00 * 0,1)+(1,00 * 0,2)+(0,20 * 0,05)+(0,60 * 0,3)=0,68$

$\mathrm{P} 11=(0,20 * 0,3)+(0,20 * 0,05)+(1,00 * 0,1)+(0,20 * 0,2)+(0,20 * 0,05)+(0,20 * 0,3)=0,28$

$\mathrm{P} 12=(0,20 * 0,3)+(1,00 * 0,05)+(1,00 * 0,1)+(1,00 * 0,2)+(0,20 * 0,05)+(0,20 * 0,3)=0,48$

$\mathrm{P} 13=(0,20 * 0,3)+(0,60 * 0,05)+(0,20 * 0,1)+(1,00 * 0,2)+(0,20 * 0,05)+(0,60 * 0,3)=0,50$

$\mathrm{P} 14=(1,00 * 0,3)+(0,60 * 0,05)+(1,00 * 0,1)+(1,00 * 0,2)+(1,00 * 0,05)+(1,00 * 0,3)=0,98$

$\mathrm{P} 15=(0,60 * 0,3)+(1,00 * 0,05)+(1,00 * 0,1)+(0,20 * 0,2)+(0,20 * 0,05)+(0,60 * 0,3)=0,56$

$\mathrm{P} 16=(0,20 * 0,3)+(0,60 * 0,05)+(1,00 * 0,1)+(1,00 * 0,2)+(1,00 * 0,05)+(1,00 * 0,3)=0,74$

$\mathrm{P} 17=(0,60 * 0,3)+(0,60 * 0,05)+(0,20 * 0,1)+(0,20 * 0,2)+(0,20 * 0,05)+(0,60 * 0,3)=0,46$

$\mathrm{P} 18=(1,00 * 0,3)+(0,20 * 0,05)+(1,00 * 0,1)+(1,00 * 0,2)+(0,60 * 0,05)+(1,00 * 0,3)=0,94$

$\mathrm{P} 19=(0,60 * 0,3)+(0,60 * 0,05)+(1,00 * 0,1)+(1,00 * 0,2)+(0,20 * 0,05)+(1,00 * 0,3)=0,82$

$\mathrm{P} 20=(0,60 * 0,3)+(0,20 * 0,05)+(0,60 * 0,1)+(0,20 * 0,2)+(0,20 * 0,05)+(0,60 * 0,3)=0,48$

$\mathrm{P} 21=(0,60 * 0,3)+(0,20 * 0,05)+(0,60 * 0,1)+(1,00 * 0,2)+(0,20 * 0,05)+(1,00 * 0,3)=0,76$

$\mathrm{P} 22=(0,20 * 0,3)+(0,60 * 0,05)+(1,00 * 0,1)+(1,00 * 0,2)+(0,20 * 0,05)+(0,20 * 0,3)=0,46$

$\mathrm{P} 23=(0,60 * 0,3)+(0,60 * 0,05)+(1,00 * 0,1)+(1,00 * 0,2)+(1,00 * 0,05)+(1,00 * 0,3)=0,86$

$\mathrm{P} 24=(0,20 * 0,3)+(0,60 * 0,05)+(0,60 * 0,1)+(1,00 * 0,2)+(0,60 * 0,05)+(0,60 * 0,3)=0,56$

$\mathrm{P} 25=(0,20 * 0,3)+(0,20 * 0,05)+(0,60 * 0,1)+(0,20 * 0,2)+(0,20 * 0,05)+(0,20 * 0,3)=0,24$

$\mathrm{P} 26=(0,20 * 0,3)+(0,60 * 0,05)+(1,00 * 0,1)+(0,20 * 0,2)+(0,60 * 0,05)+(1,00 * 0,3)=0,56$

$\mathrm{P} 27=(0,60 * 0,3)+(0,60 * 0,05)+(0,60 * 0,1)+(0,20 * 0,2)+(0,60 * 0,05)+(1,00 * 0,3)=0,64$

$\mathrm{P} 28=(0,60 * 0,3)+(0,60 * 0,05)+(0,60 * 0,1)+(1,00 * 0,2)+(0,20 * 0,05)+(1,00 * 0,3)=0,78$

$\mathrm{P} 29=(0,60 * 0,3)+(0,60 * 0,05)+(0,60 * 0,1)+(1,00 * 0,2)+(0,20 * 0,05)+(1,00 * 0,3)=0,78$

$\mathrm{P} 30=(0,60 * 0,3)+(0,60 * 0,05)+(1,00 * 0,1)+(1,00 * 0,2)+(0,20 * 0,05)+(0,20 * 0,3)=0,56$

Nilai akhir preferensi pada setiap alternatif yang telah diurutan berdasarkan rating tertinggi ke terendah, hasil perangkingan dapat terlihat pada Tabel 6 .
Tabel 6. Hasil Perangkingan

\begin{tabular}{lll}
\hline Kode & Nilai & Keterangan \\
Alternatif & & \\
\hline S14 & 0,98 & Rangking 1 \\
S18 & 0,94 & Rangking 2 \\
S03 & 0,92 & Rangking 3 \\
S23 & 0,86 & Rangking 4 \\
S29 & 0,82 & Rangking 5 \\
S28 & 0,78 & Rangking 6 \\
S21 & 0,78 & Rangking 7 \\
S16 & 0,76 & Rangking 8 \\
S04 & 0,74 & Rangking 9 \\
S09 & 0,72 & Rangking 10 \\
S10 & 0,70 & Rangking 11 \\
S05 & 0,68 & Rangking 12 \\
S02 & 0,68 & Rangking 13 \\
S27 & 0,68 & Rangking 14 \\
S06 & 0,64 & Rangking 15 \\
S30 & 0,62 & Rangking 16 \\
S24 & 0,58 & Rangking 17 \\
S15 & 0,56 & Rangking 18 \\
S26 & 0,56 & Rangking 19 \\
S01 & 0,54 & Rangking 20 \\
S13 & 0,52 & Rangking 21 \\
S20 & 0,50 & Rangking 22 \\
S12 & 0,48 & Rangking 23 \\
S20 & 0,48 & Rangking 24 \\
S22 & 0,46 & Rangking 25 \\
S17 & 0,46 & Rangking 26 \\
S08 & 0,30 & Rangking 27 \\
S11 & 0,28 & Rangking 28 \\
S25 & 0,24 & Rangking 29 \\
\hline & 0,24 & Rangking 30 \\
\hline
\end{tabular}

Dari hasil penggunaan metode Simple Addictive Weighting maka dapat ditentukan kandidat alternatif yang terbaik dan memenuhi syarat berdasarkan kriteria keputusan. Hasil proses perhitungan yang telah didapat, maka alternatif dengan nilai akhir tertinggi dengan kode alternatif S14 atas nama SDN 15 Unggan dengan nilai akhir 0,98.

\section{Kesimpulan}

Hasil akhir yang didapat dari penelitian yang telah dilakukan. Pengadopsian metode Simple Additive Weighting membantu dalam pengambilan keputusan yang tepat sasaran dalam penyaluran dana bantuan sekolah dasar, serta dapat di terapkan dengan efektif dalam memberikan usulan alternatif terbaik sesuai dengan kriteria yang telah ditetapkan.

Teknik yang berbeda bisa saja akan menghasilkan kesimpulan yang berbeda, oleh sebab itu pada penelitian selanjutnya dapat dilakukan menggunakan teknik Decission Support System seperti Analitycal Hierarchy Process, Topsis, Electre dan lainya.

\section{Daftar Rujukan}

[1] J, M. C., Suteja, B. R., Imbar, R. V., \& Zumaytis, S. (2018). Simple Additive Weighting Calculation Analysis for Bina Iman Anak Pandu School. IJCSI International Journal of Computer Science Issues, 15(5), 36-41.

[2] Setiawan, N., Nasution, M. D. T. P., Rossanty, Y., Tambunan, A.

Jurnal Informasi dan Teknologi Vol. 3 No. 2 (2021) 78-83 
R. S., Girsang, M., Agus, R. T. A., Yusuf, M., Vebrianto, R., Purba, O. N., Fuazi, A., Perdana, S., \& Nisa, K. (2018). Simple Additive Weighting as Decision Support System for Determining Employees Salary. International Journal of Engineering and Technology, 7(2).

[3] Wati, E. F., Istikharoh, I., \& Tuslaela, T. (2020). Selection of Outstanding Lecturers with Simple Additive Weighting Method. Sinkron: Jurnal dan Penelitian Teknik Informatika, 4(2). DOI: https://doi.org/10.33395/sinkron.v4i2.10513.

[4] Haswan, F. (2019). Application of Simple Additive Weighting Method to Determine Outstanding School Principals. Sinkron: Jurnal dan Penelitian Teknik Informatika, 3(2), 186-192. DOI: https://doi.org/10.33395/sinkron.v3i2.10082 .

[5] Abadi, S., Huda, M., Jasmi, K. A., Noor, S. S. M., Safar, J., Mohamed, A. K., Embong, W. H. W., Mohamad, A. M., Hehsan, A., Basiron, B., Ihwani, S. S., Maseleno, A., Muslihudin, M., Satria, F., Irawan, D., \& Hartati, S. (2018). Determination of the Best Quail Eggs Using Simple Additive Weighting. International Journal of Engineering and Technology, 7(2), 225-230. DOI: http://doi.org/10.14419/ijet.v7i2.27.11967

[6] Dogan, M., Aktar, T., Toker, O. S., \& Tatlisu, N. B. (2015). Combination of the Simple Additive (SAW) Approach and Mixture Design to Determine Optimum Cocoa Combination of the Hot Chocolate Beverage. International Journal of Food Properties, 18(8), 1677-1692. https://doi.org/10.1080/10942912.2014.917662 .

DOI:

[7] Salih, Y. K., See, O. H., Ibrahim, R. W., Yussof, S., \& Iqbal, A. (2014). A Novel Noncooperative Game Competing Model Using Generalized Simple Additive Weighting Method to Perform Network Selection in Heterogeneous Wireless Networks. Internasional Journal of Communication Systems, 1112-1125. DOI: https://doi.org/10.1002/dac.2747

[8] Sani, A., Munandar, T. A., \& Suhendar, A. (2019). Decision Supporter for Determining Priority in Supply of Shoe Raw Materials Using the Simple Additive Weighting Method. Journal of Machine Learning and Soft Computing, 1(1). DOI: https://doi.org/10.30656/jlmsc.v1i1.1669 .
[9] Trimulia, C., Defit, S., \& Nurcahyo, G. W. (2018). Pemilihan Supplier Obat yang tepat dengan Metode Simple Additive Weighting. SiTekIn Jurnal Sains, Teknologi dan Industri, 16(1), 37-42. DOI: http://dx.doi.org/10.24014/sitekin.v16i1.6735 .

[10]Sembiring, M. A. (2017). Penerapan Metode Simple Additive Weighting Sebagai Strategi Pembinaan Kecerdasan Anak. Jurteksi (Jurnal Teknologi dan Sistem Informasi), IV(1), 65-70. DOI: https://doi.org/10.31227/osf.io/np483 .

[11]Hadi, F., \& Guswandi, D. (2019). Penentuan Penerimaan Mahasiswa Baru Pascasarjana Menggunakan Simple Additive Weighting (SAW). Indonesian Journal of Computer Science, 8(2), 121-129. DOI: https://doi.org/10.33022/ijcs.v8i2.175 .

[12] Ishak, I. C., Sinsuw, A., \& Tulenan, V. (2017). Sistem Pendukung Keputusan Kelayakan Sertifikasi Guru Menggunakan Metode Simple Additive Weighting (SAW). Jurnal Teknik Informatika, 10(1). DOI: https://doi.org/10.35793/jti.10.1.2017.15923 .

13] Ayshwarya, A. P. B., Nguyen, P. T., Hashim, W., Rinjani, F., Muslihudin, M., Shankar, K., Denisova, O. P., \& Maseleno, A. (2019). The Best of Village Head Performance: Simple Additive Weighting Method. International Journal of Recent Technology and Engineering (IJRTE), 8(2S3), 1568-1572. DOI: http://doi.org/10.35940/ijrte.b1286.0782s319 .

14] Utama, Y., Fathoni., \& Ibrahim, A. (2020). Decision Support System of Advisability Assessment of Partnership Funding Recipient Using Simple Additive Weighting Method. In Sriwijaya International Conference on Information Technology and Its $\begin{array}{lll}\text { Applications } & \text { (SICONIAN 2019), 619-627. DOI: }\end{array}$ https://doi.org/10.2991/aisr.k.200424.093 .

15]Dizani, M., Sumiati, S., \& Suherman, S. (2019). Group Decision Support System for Job Promotion Using the Simple Additive Weighting (SAW) Method. Journal of Machine Learning and Soft Computing, 1(1), 34-46. DOI: https://doi.org/10.30656/jlmsc.v1i1.1673.

16]Nofriansyah., D \& Defit, S. (2017). Multi Criteria Decision Making (MCDM) pada Sistem Pendukung Keputusan. Yogyakarta :Deepublish 